\title{
Distrusted "Political Democracy"
}

\author{
BY LYLE WIISON
}

There is no good word in the United States Constitution for the political system known as "democracy" in which tellers count all the heads, empty or not, and give the decision to the most numerous.

The founding fathers rejected democracy as undesirable and established the United States as a republic, specifically guaranteeing to each state a republican form of government. (Article 4, Section 4).

In contrast to the democratic or popular headcounting political form which the Constitution rejected, the republican form is properly defined like this: A state in which the soverign power resides in the people, qualified voters, and is exercised by representatives elected by them.

It was Madison's fear that democracy favored the self-seeking maneuvers of factions or blocs within a political party.

The Journal of Constitutional Discussion indicates that the authors did not reject democracy because it was bad of itself. They rejected democracy more because it was deemed unsuitable to a nation already so large in area and numerous in population as the combined colonies of that time.

These facts are intimately related to the national and Congressional discussion expected this year seeking more satisfactory process of nominating and electing presidents of the United States. Dwight D. Eisenhower's inauguration in 1953 reminded millions of persons that they did not like many things they observed about those processes last year.

There has been national dissatisfaction with the presidential elective process and agitated discussion of it for many more than 100 years. In establishing the present Electoral College process, instead of per- 
mitting congress to elect our presidents, some of the authors of the Constitution felt that they had disposed of the most difficult of all the problems confronting them.

The direction of discussion in recent years has been generally toward more democracy and less representative republicanism in the election of presidents. There is now scattered support for abandonment of the Electoral College and for direct popular vote for president. The 17th Amendment establishing a direct popular vote for United States senators in place of their selection by state legislatures was a symptom in 1912 of what could come.

But, regardless of the 17th Amendment and the current talk of direct election of presidents, there is no doubt what the authors of the Constitution thought of political democracy. They did not trust it and were against it.

\section{The General's Failing}

At a reunion of the Indiana Association of Iowa held on the campus of Drake University at Des Moines, in August, 1887, Gen. George W. Jones, of Dubuque, exU. S. senator from Iowa, was present and made an appropriate speech, he being an Indianan, having been born in Vincennes in that state. After the exercises had been concluded, and before the general had left the stand, two ladies, Mrs. M. and Miss J., went to the stand and requested the president of the association, Judge P. M. Casady, to introduce them to the witty and polite general, which he did. The general, shaking hands, kissed each of them heartily in the presence of the large audience there assembled. The ladies blushed, and those who witnessed the scene smiled, some of them audibly. It is improbable that the ladies would have solicited an introduction if they had known the general's failing. The general said to the president he could not resist the temptation of kissing such good looking ladies.-Iowa Historical Record, Vol. 4, 5 and 6, p. 432 . 
Copyright of Annals of Iowa is the property of State of Iowa, by \& through the State Historical Society of Iowa and its content may not be copied or emailed to multiple sites or posted to a listserv without the copyright holder's express written permission. However, users may print, download, or email articles for individual use. 